\title{
ESTIMATION COMBINING ABILITY AND HETEROSIS FOR GRAIN YIELD AND ITS RELATED TRAITS IN RICE UNDER WATER STRESS CONDITION
}

\author{
Sultan, M. S.*; \\ M. A. Abdel-Moneam*; \\ A. B. El-Abd ${ }^{\star *}$ and
}

S. A. El-Naem**

* Agric. Department, Fac. of Agric., Mansoura Univ., Mansoura, Egypt.

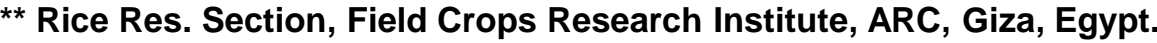

\begin{abstract}
Combining ability analysis was carried out in rice through $A 8 \times 8$ diallel set analysis excluding reciprocals involving 8 diverse parents for grain yield and some yield related traits at the Experimental Farm of Rice Research and Training Center, Sakha, Kafr El-Sheikh, Egypt during 2007 and 2008 summer seasons. The ratio of variances due to general and specific combining abilities (ó ${ }^{2}$ GCA / ó$^{2}$ SCA) was more than unity, indicating the preponderance of additive genes in controlling for 100-grain weight $(\mathrm{g})$. On the contrary, predominance of non-additive gene action chiefly controlled the expression of days to $50 \%$ heading, plant height, panicle length, number of panicles/plant, sterility (\%) and grain yield/plant. Among the parents, IET 1444, Wab 450 and Balado were found to be significantly superior general combiners for grain yield/plant. The genotypes IET 1444 and Wab 878 were good general combiners for plant height, panicle length and sterility (\%). Moreover, Balado, Wab 450 and Wab 878 were the best general combiners for 100-grain weight. On the other hand, Sakha 102, Balado and Gaori rice varieties were good combiners for earliness In addition, a total of 14 crosses exhibited positive and highly significant SCA for grain yield /plant. The promising combinations for grain yield and most of the studied traits were Sakha 102 X Sakha 104, Wab 450 X IET 1444, Wab 450 X GZ 1368 and IET $1444 \times$ Wab 878. It is observed that majority of the crosses with high SCA for grain yield were resulted from low / low or high / high or high / low combining parents. Highly significant negative estimates of SCA for number of days to $50 \%$ heading (earliness) were recorded for Wab 450 X Wab 878, Sakha 102 X Sakha 104 and Wab 450 X GZ 1368 cross combinations. Moreover, 16 cross combinations were found to be the best specific combinations for plant height. The cross combinations, Sakha 102 X IET 1444, Sakha 104 X IET 1444, Sakha 104 X Wab 878 and Wab 450 $X$ GZ 1368 were the best specific combinations for panicle length and number of panicles /plant. Ten cross combinations exhibited highly significant and negative SCA effects for sterility \%, while, nineteen crosses were the best cross combinations for 100 -grain weight. The results also revealed that, a greater magnitude of heterosis when it measured as a deviation from mid-parent and better parent was observed in Wab 450 X Wab 878, Wab 878 X Gaori, Sakha 104 X Wab 878, IET 1444 X Wab 878 , Wab 450 X Gaori and Sakha 102 X GZ 1368 rice crosses for grain yield /plant. Grain yield was positively and strongly correlated with each of number of panicles/plant (0.563), 100 grain weight (0.659) and panicle length (0.330). However, a highly significant and positive estimate of phenotypic correlation coefficient (0.574) was recorded between plant height and panicle length. On the other hand, significant negative estimates of phenotypic correlation coefficients were recorded between number of panicles/plant and each of panicle length $(-0.445)$ and 100-grain weight $(-0.295)$, and between the last ones and panicle length $(-0.312)$.
\end{abstract}

Keywords: rice, water stress, grain yield, combining ability, heterosis and phenotypic correlation coefficients. 


\section{INTRODUCTION}

Rice (Oryza sativa L.) is one of the most important cereal crops in Egypt as regards to its contribution to foreign currency. The cultivated rice area in Egypt has been increasing gradually since the beginning of the Egyptian Rice Program. The main target of The National Rice Program in Egypt is decreasing the total cultivated area in normal soil, conversely in water stress condition soil, with carrying out high yield potentiality from unit area. Water stress tolerance in dry land culture in the end of irrigated canal has been identified as a complex and growth stage-specific trait largely associated with a volume and deep root system (Chang and Loresto, 1986).

Drought, like many other environmental stresses, has adverse effects on crop yield. Low water availability is one of the major causes for crop yield reductions affecting the majority of the farmed regions around the world. As water resources for agronomic uses become more limiting, the development of drought-tolerant lines becomes increasingly more important.

The breeding of yield-rich and qualitatively better rice varieties is not possible without prior knowledge of their genetic properties. The breeders therefore try, with the help of suitable quantitative genetic methods, to combine the desired properties of different varieties. The diallel-cross method was introduced by Griffing (1956). Many commercial cultivars, besides their high agronomic performances, perform poorly in the $F_{1}$ generation, due to genetic hindrances in diverse cross combinations. Consequently, crossing in a diallel fashion is the only specific and effective technique for the measurement, identification and selection of superior genotypes (Mohammad, 2003). Estimating combining ability, diallel analysis is the first step in most plant-breeding programs aimed to improving yield and other related parameters (Pickett, 1993; Griffing, 1956).

In diallel analysis, general combining ability is regarded as additive gene action and specific combining ability reflects non-additive gene actions (Sprague and Tatum, 1942). Estimates of additive and non-additive gene action are important in early stages of breeding procedures (Dudley and Moll, 1969). Selection would be successful during the early generations when additive gene action is predominant. Otherwise, the selection would be at later generations when these effects are fixed in the homozygous lines. Diallel analysis for grain yield and its related traits could furnish interesting information about type of gene action, which would be helpful in particular situations to understand the type of gene action involved in the expression of a trait. It can identify genotypes possessing the most dominant and recessive alleles responsible for the expression of certain trait. This enables breeders to carry out efficient selection in the segregating generations, leading to the improvement of certain traits in breeding populations under water stress conditions. The present investigation aimed to estimate the general and specific combining ability and nature of gene action for grain yield and its related traits. In addition, heterosis and phenotypic correlation coefficients among all possible pairs of the studied traits were appraised. 


\section{MATERIALS AND METHODS}

The present investigation was carried out at the Experimental Farm of Rice Research and Training Center, Sakha, Kafr El-Sheikh, Egypt during 2007 and 2008 rice growing seasons. Eight local and exotic rice genotypes (inbred lines), namely, Sakha 102, Sakha 104, Balado, Wab 450, IET 1444, Wab 878, Gaori, and GZ 1368, which provided from the pure genetic stock of the Rice Research Section, Field Crops Research Institute, Agricultural Research Center, were planted in 2007 season in three successive dates of planting, ten days intervals in order to overcome the differences in flowering time between these parental genotypes. Thirty days old seedlings of each parent were individually transplanted in the permanent field in ten rows. Each row was $5 \mathrm{~m}$ long and contained 25 hills. At flowering time, a crossing program with all possible combinations between the 8 parental lines excluding reciprocals was carried out following the technique proposed by Jodon (1938) and modified by Butany (1961).

In 2008 season, 30 days old seedlings of 36 rice genotypes (8 parents and produced $28 \mathrm{~F}_{1}$ 's) were transplanted in randomized complete block design with three replications. Each replicate comprised of 10 rows of each parent and 5 rows of each $F_{1}$ hybrids. The row was $5 \mathrm{~m}$ long and 20x20 $\mathrm{cm}$ a part were maintained between rows and seedlings the evaluates experiment was planted twice, to evaluate the genotypes under normal and water stress conditions. Flush irrigation was used every 8 days for the drought conditions. Recommended cultural practices were followed for the two conditions. At maturity, days to $50 \%$ heading, plant height $(\mathrm{cm})$, number of panicles / plant, panicle length $(\mathrm{cm}), 100$-grain weight $(\mathrm{g})$, sterility percentage, and grain yield / plant $(\mathrm{g})$ were recorded for randomly chosen guarded 25 plants from the middle row / replicate using the standard evaluation system for rice, IRRI (1996).

The combining ability analysis was done following Griffing's (1956), Model 1, Method 2, where parents, and one set of $F_{1}$ 's were included to estimate the effects of general (GCA) and specific (SCA) combining ability and variance components under water stress conditions. The GCA/ SCA ratio was estimated to study the performance of the effects and to measure the relative importance of additive gene or non-additive gene effects (Singh and Chaudhary, 1979). Heterosis was estimated according to Folconer and Mackay (1996). Furthermore, appropriate L. S. D. values were calculated to test the significance of heterotic effects according to the formula suggested by Wynne et al. (1970). The phenotypic correlation coefficient was performed according to the procedure of Dewey and Lu (1959).

\section{RESULTS AND DISCUSSION}

\section{Analysis of variance}

Analyses of variance for the studied traits under investigation are presented in Table (1). The genotypes exhibited highly significant mean 
square for all the studied traits indicating wide range of genetic variability among the studied genotypes and this is a primary requirement for further computation (Virmany et al, 1997). Both general and specific combining ability variances were found to be highly significant for all traits, indicating the importance of both additive and non-additive genetic variance in determining the performance of these seven traits. General combining ability/specific combining ability ratio was used to clarify the nature of the genetic variance involved. With the exception of 100-grain weight, all traits under investigation, GCA/SCA ratio was found to be greater than unity, indicating that the additive and additive $x$ additive types of gene action were greater importance in the inheritance of this trait. Therefore, it could be concluded that the presence of large amounts of additive effects suggests the potentiality for obtaining further improvement in 100-grain weight. Also, selection procedure based on the accumulation of additive effects would be very successful in improving this trait in early generation. On the contrary, GCA/SCA ratios were found to be lower than unity for other remaining traits indicating the preponderance of non-additive genetic variance in the inheritance of days to $50 \%$ heading, plant height, panicle length, number of panicles/plant, sterility \% and grain yield/plant, therefore, selection procedure in late or advanced generation will be very important to improve these traits. However, maximize selection advance procedures which are known to be effective in shifting gene frequency when both additive and non-additive genetic variations are involved. The obtained results are in harmony with those previously observed by EL-Mowafiy (2001), EL-Refaee (2002) and Hammoud (2004). Data in Table (2) shows the Mean square of ordinary and combining ability analysis for grain yield and its related traits under normal condition for comparing with that of water stress conditions.

Table (1): Mean square estimates of ordinary and combining ability analysis for grain yield and its related traits under water stress condition.

\begin{tabular}{|l|c|c|c|c|c|c|c|c|}
\hline Source & d.f. & $\begin{array}{c}\text { days to } \\
50 \% \\
\text { heading }\end{array}$ & $\begin{array}{c}\text { Plant } \\
\text { height }\end{array}$ & $\begin{array}{c}\text { Panicle } \\
\text { length }\end{array}$ & $\begin{array}{c}\text { No. of } \\
\text { panicles } \\
\text { /plant }\end{array}$ & $\begin{array}{c}\mathbf{1 0 0} \\
\text { grain } \\
\text { weight }\end{array}$ & Sterility\% & $\begin{array}{c}\text { Grain } \\
\text { yield } \\
\text { /plant }\end{array}$ \\
\hline Genotypes & 35 & $140.91^{* *}$ & $367.58^{* *}$ & $20.48^{* *}$ & $35.13^{* *}$ & $0.51^{* *}$ & $625.98^{* *}$ & $255.62^{* *}$ \\
g.c.a & 7 & $430.02^{*}$ & $1247.13^{* *}$ & $33.52^{*}$ & $99.82^{* *}$ & $1.83^{* *}$ & $811.16^{* *}$ & $256.8^{* *}$ \\
s.c.a & 28 & $68.63^{* *}$ & $147.69^{* *}$ & $17.22^{* *}$ & $18.96^{* *}$ & $0.18^{* *}$ & $579.68^{* *}$ & $255.32^{* *}$ \\
Error & 70 & 1.71 & 6.49 & 1.28 & 2.59 & 0.004 & 5.33 & 5.33 \\
\hline g.c.a/s.c.a & \multicolumn{2}{|c|}{0.64} & 0.87 & 0.20 & 0.59 & 1.05 & 0.14 & 0.1 \\
\hline
\end{tabular}

*and ${ }^{* *}$ significant at 0.05 and 0.01 probability levels, respectively. 
Table (2): Mean square estimates of ordinary and combining ability analysis for grain yield and its related traits under normal conditions.

\begin{tabular}{|c|c|c|c|c|c|c|c|c|}
\hline Source & d.f & $\begin{array}{c}\text { days to } \\
50 \% \\
\text { heading }\end{array}$ & $\begin{array}{c}\text { Plant } \\
\text { height }\end{array}$ & $\begin{array}{c}\text { Panicle } \\
\text { length }\end{array}$ & $\begin{array}{l}\text { No. of } \\
\text { panicles } \\
\text { /plant }\end{array}$ & $\begin{array}{c}\text { 100- } \\
\text { grain } \\
\text { weight }\end{array}$ & Sterility\% & $\begin{array}{l}\text { Grain } \\
\text { yield } \\
\text { / plant }\end{array}$ \\
\hline Genotypes & 35 & $309.98^{* *}$ & $298.05^{\star *}$ & $20.38^{* *}$ & $103.68^{* *}$ & $0.52^{\star \star}$ & $703.23^{\star \star}$ & $175.41^{\star *}$ \\
\hline g.c.a & 7 & $952.24^{\star *}$ & $882.90^{* *}$ & $45.19^{\star *}$ & $270.62^{\star *}$ & $2.04^{*}$ & $451.69^{* *}$ & $172.10^{* *}$ \\
\hline s.c.a & 28 & $149.41^{* *}$ & $151.84^{\star *}$ & $14.18^{* *}$ & $61.95^{\star *}$ & $0.14^{* *}$ & $766.11^{* *}$ & $176.24^{* *}$ \\
\hline Erro & 70 & 1.28 & 4. & & 4.39 & 0.004 & & 3.38 \\
\hline g.c.a/s.c.a & & 0.64 & 0.59 & 0.33 & 0.46 & 1.53 & 0.058 & 0.097 \\
\hline
\end{tabular}

\section{Mean performance of parents and their $F_{1}$ generation}

Conspicuously, Table (3) shows that the tallest plants which are favorite for rice breeders under water stress conditions were observed in Wab 878 followed by Wab 450 and IET 1444, while, the shortest ones were exhibited in Gaori, Sakha 102 and GZ 1368 rice varieties. Balado followed by Gaori and Sakha 102, were early rice cultivars, otherwise, Wab 878, Wab 450 and GZ1368 were late rice cultivars comparing with other rice cultivars. In addition, IET 1444 has a longest panicle $(23.00 \mathrm{~cm})$ and superior grain yield (35.56 g /plant). High number of panicles/plant was detected for $\mathrm{GZ}$ 1368. Balado was found to produce the heaviest grains (3.42 g/100 grains). Low sterility \% was observed for Sakha 102, Gaori and Sakha 104 rice genotypes comparing with the other cultivated parents. The parental mean values of grain yield were ranged between 13.08 and $35.56 \mathrm{~g} /$ plant., for Wab 878 and IET 1444, respectively.

In addition, the $F_{1}$ mean values of plant height were ranged between 80.33 for (Sakha $104 \mathrm{X}$ Gaori) and $124.00 \mathrm{~cm}$ for (IET $1444 \mathrm{X}$ Wab 878) rice crosses. Plant height of eighteen rice crosses was ranged between 100 and $110 \mathrm{~cm}$, which agrees with the target of rice breeders for selection of ideal plant height under water stress conditions for resistance to lodging and suitable for mechanical harvesting. Moreover, seventeen rice crosses were earlier than 100 days and suitable to select early maturing rice genotypes. About nine rice were found to have longer panicle than the longest panicle parent, their estimated values of panicle length were ranged between 23.33 $\mathrm{cm}$ for Balado X Wab 450 and $28.33 \mathrm{~cm}$ for IET $1444 \mathrm{X}$ Wab 878. On the other hand, three crosses, namely, Balado X Wab 450, Balado X Wab 878 and Balado X IET 1444 were heavier 100 grains than the heaviest 100 grains parent (Balado). 
Sultan, M. S. et al. 
Grain yield/plant was found to be higher than the highest parent for seventeen rice crosses, indicating that over-dominance played a remarkable role in the inheritance of this trait in these counted or mentioned crosses. Moreover, grain yield/plant was controlled by partial dominance in Sakha 102 X Wab 450, Sakha 104 X Balado and IET 1444 X Gaori; their $F_{1}$ mean values were located between the values of their parental lines. Data in Table (3) shows the Mean performance of the eight parents and their $F_{1}$ generation cross for grain yield and its related traits under normal condition for comparing with that of water stress conditions.

\section{Estimates of general (GCA) and specific (SCA) combining abilities}

Obviously, estimates of GCA effects showed that the parents, Balado, Wab 450 and IET 1444 were found to be good general combiners for grain yield/plant (Table 4). High GCA effect of IET 1444 for grain yield was associated with its high GCA effect for panicle length and number of panicles /plant. The good combining ability of cultivar, Balado was due to its heaviest grains, while the high estimates of general combining ability of cultivar, Wab 450 for grain yield /plant was due to its highest estimate panicle length and 100 grain weight. The results also revealed that among the studied parents, Wab 878 followed by Wab 450 and IET 1444 were the best general combiners for short stature. Moreover, Balado, Sakha 102 and Gaori were the best general combiners for earliness. In addition, all the studied parents except GZ 1368 and Wab 450 were good combiners for sterility \%. Highly significant and positive estimates of general combining ability of panicle length were recorded for IET 1444, Wab 878, Wab 450 and Sakha 102, indicating that these four parents were the greatest combiners for improving this trait under water stress conditions. Balado, Wab 878 and Wab 450 were found to be good combiners for 100-grain weight. Generally, IET 1444 was the best one, since it possessed significant and desirable GCA effects for most of the studied traits. Data in Table (5) shows the estimates of general combining ability (GCA) effects for grain yield and its related traits under normal condition for comparing with that of water stress conditions.

Table (4): Estimates of general combining ability (GCA) effects for grain yield and its related traits under water stress condition.

\begin{tabular}{|c|c|c|c|c|c|c|c|c|}
\hline \multicolumn{2}{|c|}{ Parent } & $\begin{array}{c}\text { days to } \\
50 \% \\
\text { heading, } \\
\text { day }\end{array}$ & $\begin{array}{c}\text { Plant } \\
\text { height, } \\
\text { cm }\end{array}$ & $\begin{array}{l}\text { No. of } \\
\text { panicles } \\
\text { /plant }\end{array}$ & $\begin{array}{c}\text { Panicle } \\
\text { length, } \\
\text { cm }\end{array}$ & $\begin{array}{l}\text { 100-grain } \\
\text { weight, g }\end{array}$ & $\begin{array}{c}\text { Sterility } \\
\%\end{array}$ & $\begin{array}{c}\text { Grain } \\
\text { yield } \\
\text { /plant, g }\end{array}$ \\
\hline \multicolumn{2}{|l|}{ Sakha 102} & $-4.56^{\star *}$ & $-7.53^{\star *}$ & $-1.67^{\star *}$ & $\cdot .27^{\star \star}$ & $-0.09^{* *}$ & $-3.48^{\star *}$ & $-1.42^{\star *}$ \\
\hline \multicolumn{2}{|l|}{ Sakha 104} & $3.36^{\star \star}$ & $-4.30^{\star *}$ & $-0.94^{\star \star}$ & $-0.02^{* *}$ & $-0.10^{* *}$ & $-2.45^{\star \star}$ & $-4.27^{\star \star}$ \\
\hline \multirow{2}{*}{\multicolumn{2}{|c|}{$\begin{array}{l}\text { Balado } \\
\text { Wab } 450\end{array}$}} & $-6.43^{* *}$ & $-1.73^{\star *}$ & -0.07 & $-1.59^{* *}$ & $0.54^{* *}$ & $-1.34^{* *}$ & $2.51^{* *}$ \\
\hline & & $2.60^{* *}$ & $6.26^{\star *}$ & $-1.80^{* *}$ & $0.60^{\star *}$ & $0.05^{* *}$ & $1.12^{* *}$ & $0.55^{\star *}$ \\
\hline \multicolumn{2}{|l|}{ IET 1444} & $1.30^{\star *}$ & $5.66^{\star *}$ & $3.05^{\text {** }}$ & $1.64^{\star *}$ & $-0.08^{* *}$ & $-1.36^{\star *}$ & $5.36^{\star *}$ \\
\hline \multicolumn{2}{|l|}{ Wab 878} & $2.56^{\star \star}$ & $9.86^{\star *}$ & $-0.47^{\star *}$ & $0.80^{\star \star}$ & $0.07^{\star *}$ & $-1.30^{\star *}$ & $-1.05^{\star \star}$ \\
\hline \multicolumn{2}{|l|}{ Gaori } & $-1.76^{\star *}$ & $-6.36^{\star *}$ & $-0.60^{\star *}$ & $-0.95^{\star *}$ & $-0.13^{\star *}$ & $-3.50^{\star *}$ & $-1.74^{* *}$ \\
\hline \multicolumn{2}{|l|}{ GZ 1368} & $2.93^{\star *}$ & $-1.86^{\star *}$ & $2.52^{\star *}$ & $-0.75^{\star \star}$ & $-0.26^{\star *}$ & $12.33^{\star *}$ & 0.05 \\
\hline \multirow[t]{2}{*}{ S.E (gi) } & $: 0.05$ & 0.1 & 0.34 & 0.16 & 0.08 & 0.0002 & 0.33 & 0.33 \\
\hline & $: 0.01$ & 0.14 & 0.46 & 0.21 & 0.1 & 0.0002 & 0.45 & 0.45 \\
\hline \multirow[t]{2}{*}{ S.E (gi-gj) } & $: 0.05$ & 0.24 & 0.78 & 0.37 & 0.18 & 0.0006 & 0.76 & 0.76 \\
\hline & $: 0.01$ & 0.33 & 1.06 & 0.50 & 0.24 & 0.0008 & 1.03 & 1.03 \\
\hline
\end{tabular}

${ }^{\star}$ and ${ }^{\star \star}$ significant at 0.05 and 0.01 probability levels, respectively. 
Sultan, M. S. et al.

Table (5): Estimates of general combining ability (GCA) effects for grain yield and its related traits under normal conditions.

\begin{tabular}{|c|c|c|c|c|c|c|c|}
\hline Parent & $\begin{array}{c}\text { days to } \\
50 \% \\
\text { heading }\end{array}$ & $\begin{array}{l}\text { Plant } \\
\text { height } \\
\text { (cm) }\end{array}$ & $\begin{array}{l}\text { No. of } \\
\text { panicles } \\
\text { /plant }\end{array}$ & $\begin{array}{c}\text { Panicle } \\
\text { length } \\
\text { (cm) }\end{array}$ & $\begin{array}{c}100 \text {-grain } \\
\text { weight }(g)\end{array}$ & Sterility \% & $\begin{array}{c}\text { Grain } \\
\text { yield } \\
\text { /plant (g) }\end{array}$ \\
\hline Sakha 102 & $-6.29^{\star \star}$ & $-4.66^{\star \star}$ & $-1.20^{\star *}$ & $-\cdot .50^{\star *}$ & $-0.03^{\star \star}$ & $-8.34^{\star \star}$ & $-1.25^{\star *}$ \\
\hline Sakha 104 & $2.77^{\star \star}$ & $-5.43^{\star \star}$ & $-1.20^{\star *}$ & $-0.67^{\star *}$ & $-0.03^{\star \star}$ & $-1.25^{\star *}$ & $-0.45^{\star *}$ \\
\hline Balado & $-8.99^{\star *}$ & $-1.90^{\star *}$ & $-0.70^{\star *}$ & $-1.97^{* *}$ & $0.58^{* *}$ & $0.97^{\star *}$ & $2.81^{\star *}$ \\
\hline Wab 450 & $1.54^{\star *}$ & $3.10^{\star *}$ & $-3.97^{\star *}$ & $0.95^{\star \star}$ & $-0.002^{\star *}$ & $2.86^{* *}$ & $-1.01^{* *}$ \\
\hline IET 1444 & $5.27^{\star \star}$ & $5.90^{\star *}$ & $1.39^{* *}$ & $1.32^{\star *}$ & $-0.13^{\star \star}$ & $2.26^{\star \star}$ & $4.35^{\star \star}$ \\
\hline Wab 878 & $1.97^{\star *}$ & $7.76^{\star *}$ & $-1.74^{* *}$ & $1.59^{* *}$ & $0.09^{* *}$ & $0.74^{* *}$ & $-3.01^{* *}$ \\
\hline Gaori & $-3.29^{* *}$ & $-6.56^{\star *}$ & $1.35^{\star *}$ & $-0.84^{* *}$ & $-0.22^{\star *}$ & $-1.41^{* *}$ & $-1.15^{\star *}$ \\
\hline GZ 1368 & $7.00^{* *}$ & $1.80^{* *}$ & $6.09^{* *}$ & $0.12^{\star \star}$ & $-0.24^{\star *}$ & $4.16^{\star *}$ & $-0.28^{\star *}$ \\
\hline S.E (gi) & 0.08 & 0.25 & 0.46 & 0.04 & 0.0002 & 0.46 & 0.21 \\
\hline$: 0.01$ & 0.10 & 0.34 & 0.63 & 0.05 & 0.0002 & 0.63 & 0.28 \\
\hline S.E (gi-gj) :0.05 & 0.18 & 0.57 & 0.62 & 0.09 & 0.0006 & 1.06 & 0.48 \\
\hline$: 0.01$ & 0.24 & 0.78 & 0.58 & 0.12 & 0.0008 & 1.45 & 0.65 \\
\hline
\end{tabular}

*and ${ }^{* *}$ significant at 0.05 and 0.01 probability levels, respectively.

Therefore, it may be concluded that crosses involving these parents would result in the identification of superior segregants with favorable genes for grain yield and its related traits in this investigation. High GCA effects are related to additive and additive $X$ additive components for genetic variation, the parents with higher positive significant GCA effects are considered as good combiners, while those with negative GCA effects are poor general combiners except in case of earliness, sterility \% and selection for short stature rice. Similar results were obviously recorded by El Abd (1995), Satish and Seetharamaiah (2005), Sharma et al. (2005) and Dhakar and Vinit (2006). According to the results most of the studied genotypes were good combiners for water stress conditions, consequently successful breeding program could be conducted for drought tolerance depending on pyramiding of gene specific to the studied traits and selection must be done in a later generation for most studied traits and under controlled conditions in order to minimize environmental effects.

The estimates of specific combining ability of 28 crosses for 7 grain yield and its related traits are presented in (Table 4). It is observed that a total of 14 crosses exhibited positive and highly significant SCA effects for grain yield /plant. The promising combinations for grain yield and most of the studied traits were Sakha 102 X Sakha 104, Wab 450 X IET 1444, Wab 450 X GZ 1368 and IET 1444 X Wab 878. It is observed that the majority of the crosses with high SCA effects for grain yield were resulted from low / low or high / high or high / low combining parents. But very few crosses including low / low general combiners gave high SCA effects, except Wab 878 X Gaori cross combination, which exhibited highly significant SCA effects for all the studied traits in favorite directions.

Highly significant negative estimates of SCA for number of days to $50 \%$ heading (earliness) were recorded for Wab $450 \times$ Wab 878, Sakha 102 X Sakha 104, Wab 450 X GZ 1368, Balado X IET 1444, Wab 878 X GZ 1368, Sakha 102 X Wab 878 and Wab 878 X Gaori, cross combinations. Moreover, 
16 cross combinations were found to be the best specific combinations for plant height. The cross combinations viz., Sakha 102 X IET 1444, Sakha 104 X IET 1444, Sakha 104 X Wab 878, Wab 450 X GZ 1368, IET 1444 X Wab 878, Wab 878 X Gaori and Wab 878 X GZ 1368 were the best specific combinations for panicle length and number of panicles /plant. Ten cross combinations exhibited highly significant and negative SCA effects for sterility $\%$, while, nineteen crosses were the best cross combinations for 100-grain weight. Moreover, these cross combinations also included the parents which recorded either good or poor GCA for these traits. Among the twenty eight hybrids, almost half of them recorded highly significant positive estimates of SCA effects for grain yield/plant, (Table 4). The results revealed that there is a preponderance of non additive gene action for grain yield and most of its related traits in the hybrids resulted in high amount of vigor in $F_{1}$, selection can be postponed to later generation. These findings were in agreement with those of El Abd et al. (2003), EL-Keredy et al. (2003), Rosamma and Vijayakumar (2005), Allahgholipour and Ali (2006), Soni et al. (2006), El Abd et al. (2007), El Abd et al. (2008) and Shehata et al. (2009). Data in Table (6) shows the estimates of specific combining ability (GCA) effects for grain yield and its related traits under normal condition for comparing with that of water stress conditions.

\section{Estimates of mid and better parent heterosis}

A large number of crosses exhibited high estimates of heterosis in a desirable direction for different traits under study. The estimates of midparent and better parent heterosis for different traits are presented in (Table 5). A greater magnitude of heterosis when it measured as a deviation from mid-parent and better parent was observed in Wab $450 \times$ Wab 878, Wab 878 X Gaori, Sakha 104 X Wab 878, IET 1444 X Wab 878, Wab 450 X Gaori and Sakha $102 \times$ GZ 1368 rice crosses for grain yield /plant. The availability of sufficient hybrid vigor in several crosses in respect of grain yield suggests that a hybrid breeding program could profitably be undertaken in rice under water stress conditions. The crosses Wab 450 X Wab 878, Wab 450 X GZ 1368, and Wab 878 X GZ 1369 exhibited highest negative heterosis for days to $50 \%$ heading measured as a deviation from mid-parent and better parent, while, highly significant and negative estimates of better parent heterosis were recorded in Sakha 102X Wab 878, Sakha 102 X Sakha 104, Balado X GZ 1368 and Balado X IET 1444 for the same trait. Appearance of significant and negative heterosis for number of days to $50 \%$ heading indicated the possibility of exploiting heterosis for earliness. For plant height, further, most of the studied crosses recorded significant mid and better parent heterosis in a desirable positive direction. Approximately, high estimated values of mid and better parent heterosis were reported in Wab 878 X Gaori, Wab 450 X Wab 878 and IET 1444 x Wab 878 exhibited highly significant and positive estimates of heterosis for number of panicles/plant. Often, all the studied crosses included Wab 878 as a male parent exhibited highly significant positive estimates of better parent heterosis for number of panicles/plant. Moreover, highly significant and positive estimates of mid and better parent 
heterosis were observed for panicle length in several crosses, the highest estimated values were observed in IET 1444 X Wab 878 (23.17 and 34.90) and Sakha $104 \times$ Wab 878 (24.52 and 34.52), respectively. On the other hand, among 28 crosses, only six crosses recorded significant positive mid and better parent heterosis for 100-grain weight. Very few crosses recorded significant negative either mid or better parent heterosis for sterility \%, while, the most of other remaining crosses recorded highly significant magnitude of mid and better parent heterosis in positive direction. Similar results were reported by several scientists like, EL-Mowafiy (2001), El Abd et al. (2003), EL-Keredy et al. (2003), Chitra et al. (2006), Saravanan et al. (2006), Senguttuvel et al. (2006), Shanthala et al. (2006), El Abd et al. (2007). Data in Table (8) shows the estimates of heterosis as a deviation from mid and better parent of the twenty eight rice crosses for grain yield and some of its related traits under normal condition for comparing with that of water stress conditions.

\section{Estimates of phenotypic correlation coefficients}

The phenotypic correlation coefficients among all possible pairs of grain yield component traits are presented in Table (6). Lucidly, grain yield was positively and strongly correlated with each of number of panicles/plant (0.563), 100 grain weight $(0.659)$ and panicle length $(0.330)$. This result indicated that these traits were found to be the principle yield components. Therefore, any selection based on these traits will bring the desired improvement in grain yield. Sterility \% showed significant either positive correlation with panicle length (0.385) and number of panicles/plant $(0.345)$ or negative with each of days to $50 \%$ heading $(-0.368)$ and grain yield/plant $(-0.375)$. Among yield related traits, days to $50 \%$ heading was significantly and positively associated with panicle length $(0.424)$ and 100 grain weight (0.406). However, a highly significant and positive estimate of phenotypic correlation coefficient $(0.574)$ was recorded between plant height and panicle length. On the other hand, significant negative estimates of phenotypic correlation coefficients were recorded between number of panicles/plant and each of panicle length (-0.445) and 100-grain weight $(-0.295)$, and between the last ones with panicle length $(-0.312)$. Present findings coincide with the results of Deng, HuiMing et al. (2005), Patil and Sarawgi (2005), Satyanarayana et al. (2005) and El Abd et al. (2008). However, the current results do not coincide with the findings of Islam et al. (2002), who reported that grain yield per plant was positively correlated with plant height. The difference in results may be attributed to the difference in genetic material and environmental condition of the experiment. Data in Table (9) shows the estimates of phenotypic correlation coefficients among all possible pairs of grain yield and its related traits under normal condition for comparing with that of water stress conditions. 
J. of Plant Production, Vol. 1 (4), April, 2010 
Sultan, M. S. et al. 
J. of Plant Production, Vol. 1 (4), April, 2010

8

559 
Sultan, M. S. et al.

9 


\section{REFERENCES}

Allahgholipour, M. and A. J. Ali. 2006. Gene action and combining ability for grain yield and its components in rice. J. Sustain. Agric., 28(3):39-53.

Butany, W. T. 1961. Mass emasculation in rice. Inster. Rice Comm. Newsletter. 9: 9-13.

Chang, T. T. and G. C. Loresto. 1986. Screening techniques for drought resistance in rice. In Approaches for Incorporating Drought and Salinity Resistance in Crop Plants, edited by V. L. Chopra and R. S. Paroda. 108-29.

Chitra, S., C. R. A. Kumar and L. Subha. 2006. Studying heterosis for grain yield and its components in $F_{1}$ (hybrid) rice. Research on Crops, 7(2):437-439.

Deng, HuiMing, Zou, Xiao Yun and Song, Yu. 2005. The analysis of correlation and path coefficient in the yield character of two-line hybrid rice. Acta Agric. Univ. Jiangxiensis, 27(1): 68-71.

Dewey, D. R. and K. H. Lu. 1959. A correlation and path-coefficient analysis of components of crested wheat grass seed production. Agron. J. 51: $515-518$.

Dhakar, J. M. and V. Vinit. 2006. Combining ability analysis in rice (Oryza sativa). Crop Research Hisar, 31(3):378-379.

Dudley, J. W. and R. H. Moll. 1969. Interpretation and use of estimates of heritability and genetic variance in plant breeding. Crop Sci. 9: 257262.

EL-Abd, A. B. 1995. Inheritance of yield and yield components in rice. M.S. Thesis, Fac. of Agric., Al-Azhar Univ., Egypt.

EL-Abd, A. B., A. A. Abd Allah and A. A. El-Hissewy. 2003. Studies on combining ability and heterosis for some physiological characters in rice (Oryza sativa L.). Proc. 10th National Conference of Agronomy, Fac. of Environ. Sci., El-Arish, Suez Canal Univ., Egypt, 7-10 october, 81-93.

EL-Abd, A. B., A. A. Abd Allah, S. M. Shehata, A. S. M. Abd El-Lateef and B. A. Zayed. 2007. Heterosis and combining ability for yield and its components and some root characters in rice under water stress conditions. Proc. Fifth Plant Breeding Conference, May 27. Egypt. J. Plant Breeding, Special Issue, Vol. 11 (2): 593-609.

EL-Abd, A. B., S. E. M. Sedeek, S. A. A. Hammoud and A. A. Abd Allah. 2008. Studies on genetic variability, heritability and genetic advance for grain yield and grain quality traits in some promising genotypes of rice (Oryza sativa L.). J. Agric. Res., Kafer El-Sheikh Univ., 34(1): 73-97.

EL-Keredy, M. Sh., A. A. El-Hissewy, M. S. Abd El-Aty, A. B. EL-Abd and H. M. Hassan. 2003. Heterosis and combining ability analysis for agronomic, yield and its component characters in rice (Oryza sativa L.). Proc. 10th National Conference of Agronomy, Fac. of Environ. Sci., ElArish, Suez Canal Univ., Egypt, 7-10 october, 160-175.

EL-Mowafy, H. F. 2001. Study on heterosis in hybrid rice under Egyptian conditions. Egypt. J. Appl. Sci., 16 (2) :52-63. 
EL-Refaee, Y. Z. A. 2002. Genetical and biochemical studies on heterosis and combining ability in rice. M.Sc. Thesis, Genetic, Dept, Fac. of. Agric. Kafr. El-Sheikh, Tanta University, Egypt.

Falconer, D. S. and F.C. Mackey. 1996. Introduction to quantitative genetics. Fourth Edition. Longman. New York.

Griffing, B. 1956 (a). A generalized treatment of the use of diallel crosses in quantitative inheritance. Heredity 10. 31-50.

Hammoud, S. A. A. 2004. Inheritance of some quantitative characters in rice (Oryza stiva L.). ph. D.Thesis, Fac. of. Agric. Minufiya University, Shibin El-Kom, Egypt.

IRRI (International Rice Research Institute). 1996. Standard evaluation System for Rice. International Rice Research Institute (IRRI), P.O. Box 933, 1099 Manila, Philippines.

Islam, A., P. K. Duara and P. K. Barua. 2002. Genetic variability in a set of rice bean genotypes assessed over sowing dates. J. Agric. Sci. Society of North East India, 15(1): 61-66.

Jodon, N. E. 1938. Experiment on artificial hybridization of rice. J. Amer. Soci. Argon., 30: 249-305.

Mohammad Subhan, M. 2003. Diallel analysis for estimating combining ability of quantitatively inherited traits in upland cotton. Asian J. Plant Sci., 2(11): 853-857. Paroda. 108-29.

Patil, P. V. and A. K. Sarawgi. 2005. Studies on genetic variability, correlation and path analysis in traditional aromatic rice accessions. Annals of Plant Physiol. 19(1): 92-95.

Pickett, A. A. 1993. Hybrid wheat-Result and Problems. Plant breeding 15. Berlin : Paul Parey Sc Publish, pp. 1-58.

Rosamma, C. A. and N. K. Vijayakumar. 2005. Heterosis and combining ability in rice (Oryza sativa L.) hybrids developed for Kerala State. Indi J. Genetics and Plant Breedi, 65(2):119-120.

Saravanan, K., V. Anbanandan and P. S. Kumar. 2006. Heterosis for yield and yield components in rice (Oryza sativa L.). Crop Research Hisar, 31(2):242-244.

Satish, Y. and K. V. Seetharamaiah. 2005. Combining ability analysis for yield and its component characters in rice (Oryza sativa L.). Annals of Biology, 21(2):149-153.

Satyanarayana, P. V., T. Srinivas, P. R. Reddy, L. Madhav-ilatha and Y. Suneetha. 2005. Studies on variability, correlation and path coefficient analysis for restorer lines in rice (Oryza sativa L.). Research on Crops, $6(1): 80-84$

Senguttuvel, P., J. R. K. Bapu and K. S. Pandian. 2006. Heterosis breeding in rice for higher yields. Plant Archives, 6(1):261-263.

Shanthala, J., J. Latha and H. Shailaja. 2006. Heterosis of rice (Oryza sativa L.) hybrids for growth and yield components. Research on Crops, $7(1): 143-146$. 
Sharma, P. R., P. Khoyumthem, N. B. Singh and K. N. Singh. 2005. Combining ability studies for grain yield and its component characters in rice (Oryza sativa L.). Indian J. Genetics and Plant Breedi, 65(4):290-292.

Shehata, S. M., A. B. EL-Abd, A. S. M. Abd El Lattef and E. A. S. Badr. 2009. Combining ability for grain yield and brown spot disease resistance traits in rice (Oryza sativa L.) under saline soil conditions. J. Agric. Sci., Mansoura Univ., 34(3): 2017-2039.

Singh, R. K. and B. D. Chaudhary. 1979. Biometrical Methods in Quantitative Genetic Analysis. Kalyani Publ., New Delhi.

Soni, D. K., A. K. Sarawagi and A. Kumar. 2006. Combining ability studies for seed yield and its related components in rice (Oryza sativa L.). Plant Archives, 6(1):213-216.

Sprague, G. F. and Tatum, L. A. 1942. General vs. specific combining ability in single crosses of corn. J. Amer. Soc. Agron. 34: 923-932.

Wynne, J. C., D. A. Emery and P. W. Rice. 1970. Combining ability estimates in Arachis hypogea L. II- Field performance of $F_{1}$ hybrids. Crop Sci., 10.

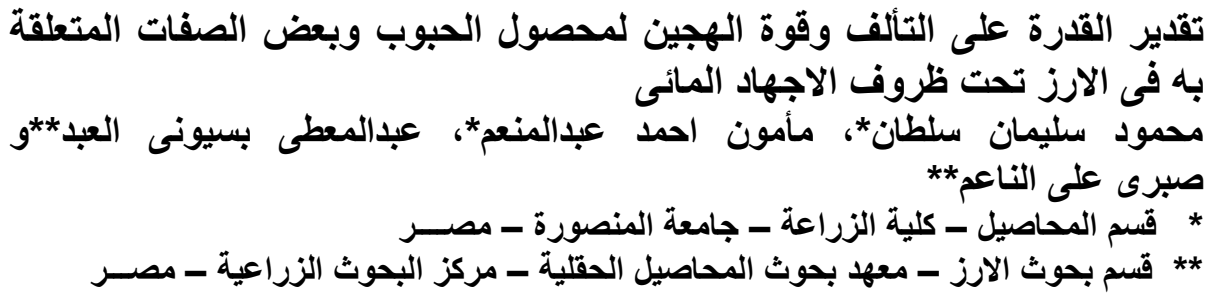

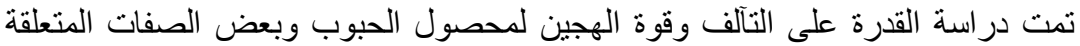

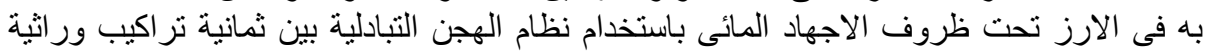

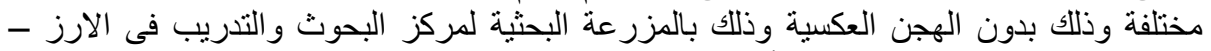

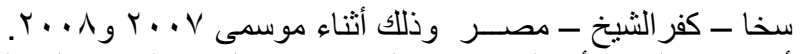

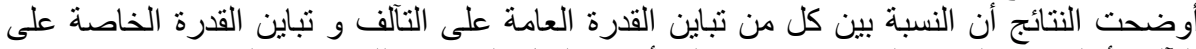

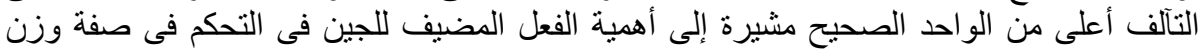

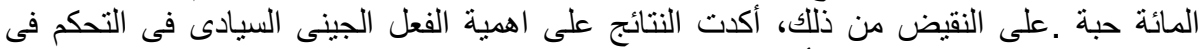

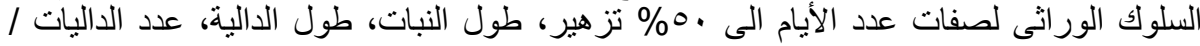

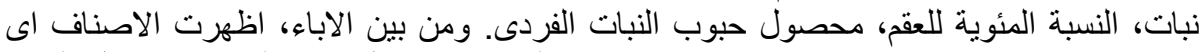

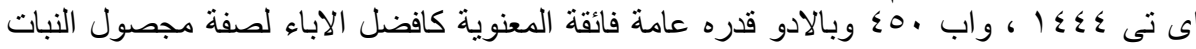

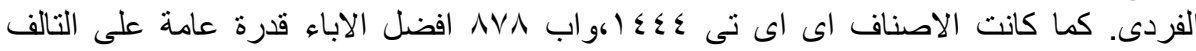

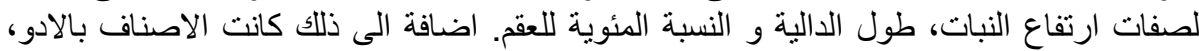

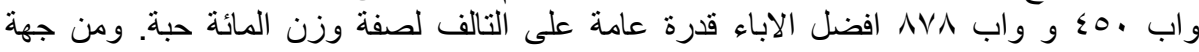

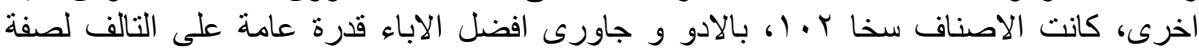
التبكير.

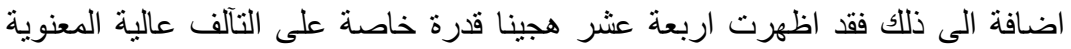

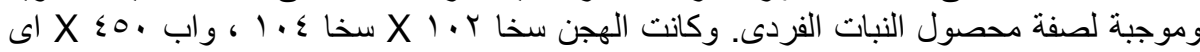

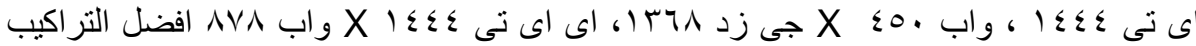
الور اثية قدرة خاصة على التالف لمحصول الحبوب ومعظم الصفات المدروسة ـكما اظهرت الناب النتائج 


\section{Sultan, M. S. et al.}

ان بعض الهجن ذات القدرة الخاصة الفائقة على التالف لصفة محصول الحبوب كانت نتيجة التهجين

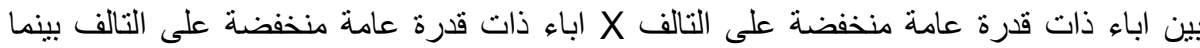

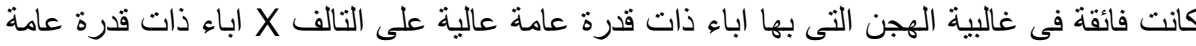

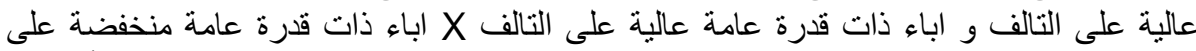

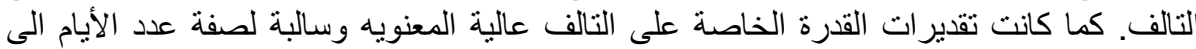

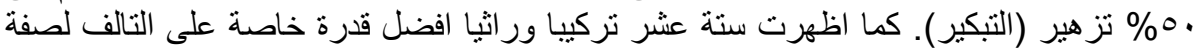

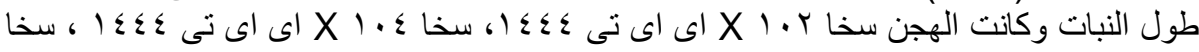

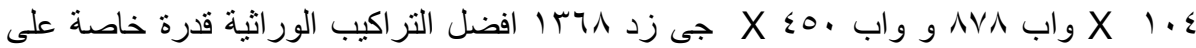

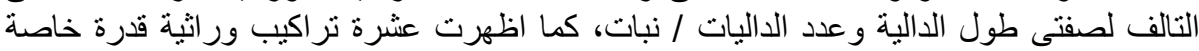
عالية المعنوية وسالبة لصفة وزن الصنة المائة حبة.

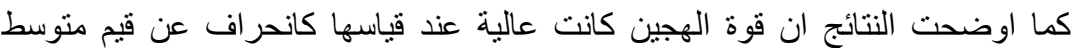

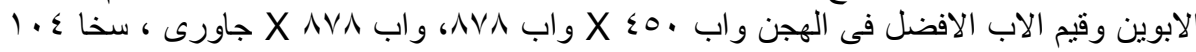

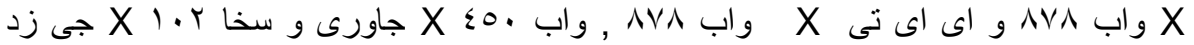

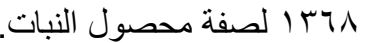

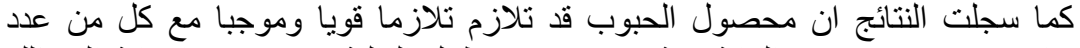

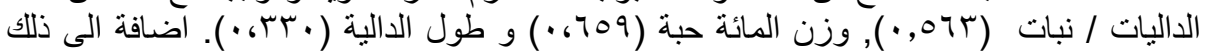

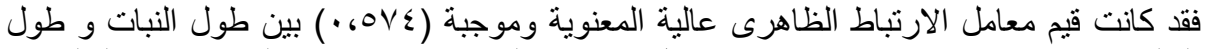

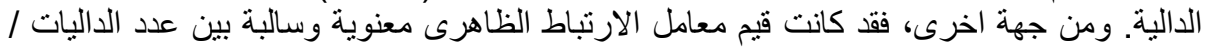

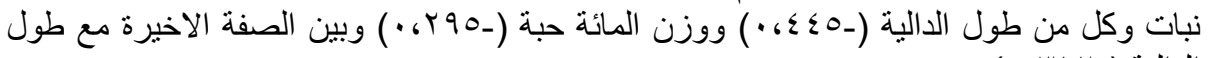

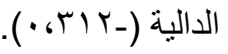

كلية الزراعة - جامعة المنصورة كلية الزراعة - جامعة كفر الثيخ
قام بتحكيم البحث

أ. أد / أحمد نادر السيد البهيد عطيه

أ.د / أد / عبد العزيز جلادل إبراهيم 
J. of Plant Production, Vol. 1 (4), April, 2010 
J. of Plant Production, Vol. 1 (4): 547 - 564, 2010

Table (3): Mean performance of the eight parents and their $F_{1}$ generation of $8 \times 8$ diallel cross for grain yield and its related traits.

\begin{tabular}{|c|c|c|c|c|c|c|c|c|c|c|c|c|c|c|c|}
\hline \multirow{2}{*}{\multicolumn{2}{|c|}{ Genotype }} & \multicolumn{2}{|c|}{$\begin{array}{l}\text { days to } 50 \% \\
\text { heading, day }\end{array}$} & \multicolumn{2}{|c|}{ Plant height, cm } & \multicolumn{2}{|c|}{\begin{tabular}{|c|}
$\begin{array}{c}\text { No. of panicles } \\
\text { /plant }\end{array}$ \\
\end{tabular}} & \multicolumn{2}{|c|}{\begin{tabular}{|c} 
Panicle length, \\
cm
\end{tabular}} & \multicolumn{2}{|c|}{$\begin{array}{l}\text { 100-grain } \\
\text { weight, g }\end{array}$} & \multicolumn{2}{|c|}{ Sterility \% } & \multicolumn{2}{|c|}{$\begin{array}{l}\text { Grain yield } \\
\text { /plant, } \mathrm{g}\end{array}$} \\
\hline & & D & $\mathbf{N}$ & D & $\mathbf{N}$ & D & $\mathbf{N}$ & D & $\mathbf{N}$ & D & $\mathbf{N}$ & D & $\mathbf{N}$ & & $\mathbf{N}$ \\
\hline \multirow{15}{*}{\begin{tabular}{|l} 
Sakha 102 \\
Sakha 104 \\
Balado \\
Wab 450 \\
IET 1444 \\
Wab 878 \\
Gaori \\
GZ 1368 \\
Sakha 102
\end{tabular}} & & 90.33 & 88.33 & 78.66 & 103.66 & 10.66 & 17.33 & 19.33 & 24.66 & 2.60 & 2.83 & 4.18 & 3.08 & 26.83 & 36.66 \\
\hline & & 96.33 & 97.00 & 91.00 & achor & 13.00 & 18.00 & 19.00 & 23.00 & 2.64 & 2.98 & 7.85 & 3.52 & & 38.00 \\
\hline & & 85.66 & 84.00 & 91.33 & 107.33 & 14.66 & 21.33 & 17.33 & 19.00 & 3.42 & 3.73 & 10.79 & 4.47 & 34.70 & 46.33 \\
\hline & & 102.66 & 98.00 & 100.66 & 109.00 & 9.00 & 13.33 & 21.33 & 24.33 & 2.72 & 3.06 & 17.92 & 9.22 & 30.13 & 35.00 \\
\hline & & 95.33 & 97.00 & 98.00 & 111.66 & 18.00 & 21.33 & 23.00 & 24.33 & 2.22 & 2.36 & 25.4 & 22.98 & 35.56 & 45.00 \\
\hline & & 103.00 & 99.00 & 109.33 & 122.00 & 9.00 & 13.66 & 19.00 & 26.00 & 2.74 & 2.84 & 14.97 & 11.23 & 18.13 & 21.33 \\
\hline & & & 85.00 & 75.33 & 95.33 & 11.66 & 19.66 & 19.00 & 20.00 & 2.47 & 2.52 & 7.44 & 30.32 & 26.83 & 32.00 \\
\hline & & 102.00 & 115.00 & 89.66 & 118.66 & 19.00 & 28.33 & 19.33 & 23.33 & 2.10 & 2.21 & 11.92 & 6.04 & 31.33 & 40.00 \\
\hline & x Sakha 104 & 89.66 & 87.70 & 90.66 & 114.00 & 14.66 & 28.30 & 20.66 & 21.00 & 2.57 & 3.03 & 8.63 & 6.84 & 37.13 & 45.70 \\
\hline & & 88.33 & 84.00 & 93.00 & 110.00 & 16.00 & 23.30 & 20.66 & 22.30 & 2.86 & 3.85 & 12.22 & 7.90 & 37.23 & 48.00 \\
\hline & $\mathrm{x} \mathrm{Wal}$ & 96.66 & 90.30 & 102.00 & 120.00 & 12.00 & 17.70 & 18.33 & 21.30 & 2.76 & 3.00 & 34.95 & 4.11 & 27.23 & 32.70 \\
\hline & $x$ IET & 91.00 & 88.30 & 105.33 & 124.00 & 19.66 & 27.00 & 25.66 & 25.00 & 2.63 & 2.73 & 24.59 & 25.1 & 38.36 & 47.70 \\
\hline & $\mathrm{x} \mathrm{Wal}$ & 91.66 & 86.00 & 98.00 & 112.00 & 13.00 & 19.00 & 22.33 & 22.00 & 2.45 & 2.82 & 9.77 & 7.50 & & 37.00 \\
\hline & $x \mathrm{Gac}$ & 91.00 & 93.00 & 86.66 & 101.00 & 10.33 & 21.33 & 22.33 & 22.00 & 2.55 & 2.72 & 14.59 & 8.91 & 36.56 & 47.00 \\
\hline & $x$ GZ & 101.66 & 94.00 & 89.65 & 106.00 & 16.66 & 29.70 & 20.66 & 22.30 & 2.62 & 2.86 & 49.30 & 1.33 & 45.13 & 47.70 \\
\hline \multirow[t]{6}{*}{ Sakha 104} & x Balado & 95.00 & 89.00 & 94.66 & 108.00 & 13.33 & 20.70 & 20.33 & 20.70 & 3.37 & 3.75 & 23.42 & 18.9 & 28.93 & 48.30 \\
\hline & $x$ Wa & 106.66 & 96.00 & 105.00 & 119.00 & 10.00 & 13.30 & 20.66 & 18.70 & 2.62 & 2.84 & 18.86 & 15.8 & 22.53 & 35.00 \\
\hline & $x$ IE & 107.00 & 111.00 & 105.33 & 125.00 & 19.00 & 26.70 & 24.33 & 25.70 & 2.18 & 2.79 & 27.81 & 17.8 & 26.50 & 53.00 \\
\hline & $x$ Wa & 114.66 & 104.00 & 108.00 & 118.00 & 15.66 & 21.00 & 23.66 & 26.00 & 2.46 & 2.90 & 16.90 & 9.62 & 41.33 & 48.00 \\
\hline & $x G_{a}$ & 96.00 & 90.00 & 80.33 & 100.00 & 14.33 & 27.00 & 20.66 & 20.70 & 2.54 & 2.62 & 8.92 & 6.95 & 20.03 & 40.30 \\
\hline & $x \mathbf{G}$ & 108.33 & 119.00 & 89.00 & & 18.00 & 28.00 & 21.00 & 25.00 & 2.43 & 2.72 & 54.11 & 55.8 & 21.26 & 40.70 \\
\hline \multirow[t]{5}{*}{ Balado } & x Wab 450 & 95.00 & 87.00 & 104.00 & 122.00 & 13.33 & 18.00 & 23.33 & 24.70 & 3.65 & 3.55 & 33.15 & 61.5 & 25.66 & 35.30 \\
\hline & & 88.00 & 84.00 & 105.00 & 118.00 & 19.00 & 23.30 & 17.66 & 20.70 & 3.52 & 3.69 & 12.03 & 7.48 & 6 & 54.00 \\
\hline & x Wab 878 & 95.00 & 85.00 & 110.00 & 126.00 & 15.66 & 26.00 & 18.66 & 20.30 & 3.56 & 3.80 & 32.59 & 25.3 & 35.90 & 43.00 \\
\hline & & 89.00 & 88.00 & 9433 & 105.00 & 15.33 & 25.00 & 17.32 & 21.70 & 3.07 & 3.35 & 10.78 & 4.47 & 42.73 & 49.00 \\
\hline & $x$ GZ & 90.33 & 88.00 & 97.00 & 119.00 & 17.66 & 27.00 & 20.66 & 22.30 & 3.14 & 3.33 & 37.02 & 20.6 & 42.13 & 49.30 \\
\hline \multirow[t]{4}{*}{ Wab 450} & $x$ IET & 106.00 & 111.00 & 116.66 & 131.00 & 17.00 & 19.70 & 25.33 & 26.30 & 2.74 & 2.82 & 17.85 & 13.7 & 45.90 & 51.70 \\
\hline & x Wab 878 & 95.00 & 98.00 & 110.66 & 119.00 & 14.66 & 16.00 & 21.66 & 27.70 & 3.03 & 3.24 & 9.44 & 7.01 & 46.30 & 50.70 \\
\hline & & & 100.00 & 109 & & 19.33 & 25.30 & & 28.30 & 2.24 & 2.51 & 18.35 & 13.2 & & 54.70 \\
\hline & x GZ 1368 & 97.00 & 100.00 & 112.00 & 122.00 & 18.00 & 36.70 & 22.66 & 24.30 & 2.64 & 2.88 & 41.32 & 46.2 & 46.13 & 51.30 \\
\hline \multirow[t]{3}{*}{ IET 1444} & x Wab 878 & 104.00 & 123.00 & 124.00 & 137.00 & 21.33 & 24.30 & 28.33 & 30.30 & 3.25 & 3.39 & 24.99 & 33.9 & 49.40 & 54.00 \\
\hline & x Gao & 102.00 & 99.00 & 102.66 & 120.00 & 17.33 & 28.70 & 21.66 & 23.70 & 2.79 & 2.86 & 19.68 & 26.9 & 29.33 & 39.00 \\
\hline & $x \mathrm{GZ}$ & 100.66 & 105.00 & 99.66 & 123.00 & 21.66 & 34.70 & 20.66 & 23.30 & 2.13 & 2.59 & 8.5 & 3.16 & 39.93 & 45.70 \\
\hline \multirow[t]{2}{*}{ Wab 878} & x Gaori & 96.00 & 91.00 & 112.66 & 126.00 & 18.00 & 30.30 & 23.66 & 23.00 & 2.72 & 3.03 & 14.16 & 7.70 & 42.33 & 49.00 \\
\hline & x GZ 1368 & & 98.00 & 114.66 & 131.00 & 19.33 & 31.70 & 23.66 & 25.00 & 2.36 & 3.10 & 45.69 & 45.3 & 31.80 & 37.00 \\
\hline \multirow[t]{3}{*}{ Gaori } & x GZ 1368 & 104.00 & 99.00 & 98.00 & 117.00 & 16.33 & 29.70 & 21.33 & 22.70 & 2.33 & 2.63 & 60.79 & 8.42 & 32.96 & 37.00 \\
\hline & 0.05 & 2.13 & $\begin{array}{l}T, \wedge \leqslant \\
Y, \leqslant \leqslant\end{array}$ & 4.14 & 3.26 & 2.62 & $r, \xi Y$ & 1.84 & $\begin{array}{l}1.30 \\
170\end{array}$ & $\begin{array}{c}0.1 \\
0.12\end{array}$ & 0.10 & 3.76 & 4.46 & 3.76 & 3.00 \\
\hline & & & & & & & 0 & & 1.72 & 0.13 & 0.13 & & .93 & 5.00 & 3.99 \\
\hline
\end{tabular}

*and ** significant at 0.05 and 0.01 probability levels, respectively 
Table (6): Estimates of specific combining ability (SCA) effects for grain yield and its related traits.

\begin{tabular}{|c|c|c|c|c|c|c|c|c|c|c|c|c|c|c|c|}
\hline \multicolumn{2}{|c|}{ Genotype } & \multicolumn{2}{|c|}{$\begin{array}{l}\text { days to } 50 \% \\
\text { heading }\end{array}$} & \multicolumn{2}{|c|}{$\begin{array}{l}\text { Plant height } \\
\text { (cm) }\end{array}$} & \multicolumn{2}{|c|}{$\begin{array}{c}\text { No. of panicles } \\
\text { /plant }\end{array}$} & \multicolumn{2}{|c|}{$\begin{array}{l}\text { Panicle length } \\
\text { (cm }\end{array}$} & \multicolumn{2}{|c|}{$\begin{array}{l}\text { 100-grain weight } \\
\text { (g) }\end{array}$} & \multicolumn{2}{|c|}{$\begin{array}{c}\text { Sterility } \\
\%\end{array}$} & \multicolumn{2}{|c|}{$\begin{array}{c}\text { Grain } \\
\text { yield/plant } \\
\text { (g) }\end{array}$} \\
\hline & & D & $\mathbf{N}$ & D & $\mathbf{N}$ & D & $\mathbf{N}$ & D & $\mathbf{N}$ & D & $\mathbf{N}$ & D & $\mathbf{N}$ & D & $\mathbf{N}$ \\
\hline \multirow[t]{7}{*}{ Sakha 102} & x Sakha 104 & $-6.50^{* *}$ & $-4.69^{\star *}$ & $2.77^{*}$ & $8.32^{* *}$ & $1.68^{* *}$ & $7.07^{* *}$ & 0.16 & $-1.19^{* \star}$ & $0.03^{\star *}$ & $0.10^{\star \star}$ & $-7.35^{\star \star}$ & -0.37 & $7.63^{\star *}$ & $3.86^{\star \star}$ \\
\hline & & $1.96^{\star \star}$ & $3.40^{*}$ & $2.48^{*}$ & 0.78 & $2.14^{\star \star}$ & 1.57 & $0.73^{\star *}$ & $1.43^{\star \star}$ & $2^{\star *}$ & $30^{\star *}$ & $-4.87^{\star \star}$ & -1.5 & & $93^{\star *}$ \\
\hline & & $1.26^{\star *}$ & $-0.79^{* *}$ & $3.48^{*}$ & $6.12^{\star \star}$ & -0.11 & -0.82 & $-3.13^{\star \star}$ & $-2.49^{\star \star}$ & $6 * *$ & $0.03^{\star *}$ & $15.39^{\star \star}$ & $-7.21^{* *}$ & $-7.76^{* *}$ & $-8.56^{\star *}$ \\
\hline & & $-3.10^{* *}$ & -6.53 & $7.42^{\star \star}$ & 7.32 & $2.68^{* *}$ & $3.14^{\star \star}$ & $2.50^{* *}$ & 0.8 & & -1.10 & 7.5 & $14.37^{* *}$ & -0.77 & 1.06 \\
\hline & $x W$ & $-3.70^{* *}$ & $-5.56^{\star *}$ & $-4.11^{* *}$ & $-6.54^{\star *}$ & -0.45 & -1.72 & $1.00^{* *}$ & $-2.46^{\star *}$ & $6^{\star *}$ & $-0.24^{\star *}$ & $-7.35^{\star *}$ & -1.71 & $-4.82^{* *}$ & $-2.23^{\star *}$ \\
\hline & & -0.03 & 6.70 & 0.78 & -3.2 & $-2.98^{\star \star}$ & $-2.49^{\star \star}$ & $2.10^{\star \star}$ & $-0 .($ & ${ }^{\star \star}$ & & & 1.8 & & $5.90^{\star \star}$ \\
\hline & $x \mathbf{G}$ & $5.93^{\star *}$ & $-2.59^{* *}$ & -0.71 & $-7.24^{\star *}$ & 0.21 & 1.10 & 0.23 & $-0.66^{\star \star}$ & $5^{\star \star}$ & & $18.53^{\star *}$ & $-11.30^{\star *}$ & $11.29^{* \star}$ & $5.70^{\star *}$ \\
\hline \multirow[t]{6}{*}{ Sakha 104} & $\times \mathrm{Ba}$ & 0.6 & -0.6 & 0.92 & & & -1.0 & & & & & & & & $2.46^{\star *}$ \\
\hline & 50 & $3.33^{\star \star}$ & -4 & $3.25^{\star \star}$ & $2^{\star \star}$ & $-2.85^{\star \star}$ & $-5.15^{\star \star}$ & $-1.16^{\star \star}$ & -4 . & *** & & -1.71 & -2.64 & $-7.27^{\star \star}$ & $-703^{\star \star}$ \\
\hline & & $4.96^{\star \star}$ & 7.4 & $4.18^{\star}$ & $8.75^{\star \star}$ & $1.28^{*}$ & $2.80^{\star \star}$ & $1.46^{\star \star}$ & & & & & & & $5.60^{\star *}$ \\
\hline & & 11.3 & & $2.6 \mathrm{~s}$ & -0 . & $1.48^{\star *}$ & 0.2 & & & & & & -6.6 & & $7.96^{\star \star}$ \\
\hline & & & -5.3 & -8.7 & & 0.2 & & & & & & & & & $--1.56^{\star \star}$ \\
\hline & & & 13.3 & $-4.61^{\star *}$ & -7.1 & 0.8 & -0.5 & & & & & & & -9. & $-2.10^{\star *}$ \\
\hline \multirow[t]{5}{*}{ Balado } & 450 & $1.46^{\star *}$ & $-1.43^{\star *}$ & -0.31 & $5.35^{\star *}$ & -0.38 & -0.99 & $3.40^{* *}$ & & ** & -0.0 & $11.45^{\star *}$ & $40.84^{\star *}$ & $0.26^{* *}$ & $-9.96^{* *}$ \\
\hline & & 8 & & 1.2 & & 0.41 & & -3.6 & & & & & -12 & & $3.33^{\star \star}$ \\
\hline & & $1.49^{\star \star}$ & -3.8 & 2.08 & 4.3 & 0.6 & $4.77^{\star \star}$ & -0 . & -2.6 & & & $14.32^{\star \star}$ & $6.79^{\star \star}$ & 0.1 & -0.30 \\
\hline & & & & 2.65 & & & & & & & & & & & \\
\hline & & -3.5 & -5.8 & 0.8 & & -0.38 & -2. & 3.1 & & & & $4.11^{\star *}$ & -1.32 & -0. & $3.30^{\star *}$ \\
\hline \multirow[t]{4}{*}{ Wab 450} & & & & 4.95 & & 0.14 & & & & & & & & & \\
\hline & & & 1 & -5.24 & & 13 & -1. & & & & & $2^{* *}$ & $1^{* \star}$ & 11. & $11.20^{\star *}$ \\
\hline & & & 5.87 & $9.32^{*}$ & $3.68^{* *}$ & $6.14^{\star *}$ & $4.27^{\star \star}$ & 0.4 & 4.8 & ** & $-0.26^{\star *}$ & -1.17 & $-5.08^{\star *}$ & $15.29^{\star \star}$ & $13.33^{\star *}$ \\
\hline & & & 113 & $782 *$ & & & $10.87^{* *}$ & 0 & & & & & & & $9.13^{\star \star}$ \\
\hline \multirow[t]{3}{*}{ IET 1444} & $\mathrm{x}$ Wa & $2.76^{\star \star}$ & $19.87^{\star \star}$ & $8.68^{\star \star}$ & $7.55^{\star \star}$ & $3.14^{\star *}$ & 1.00 & $2.96^{\star *}$ & 4.0 & 0.5 & 0.4 & $5.74^{\star \star}$ & $14.01^{\star \star}$ & $9.88^{* \star}$ & $9.16^{\star \star}$ \\
\hline & & & & & & & & & & & & & & & \\
\hline & & & -3.1 & -3.9 & & 0. & $3.50^{* *}$ & -1.4 & & & * & $-24.38^{\star *}$ & $8^{\star *}$ & -0.69 & $-1.90^{* *}$ \\
\hline \multirow[t]{2}{*}{ Wab 878} & $x \mathrm{Gac}$ & $-2.17^{\star *}$ & -3.56 & 9.38 & $9.35^{\star *}$ & $3.48^{* *}$ & $7.04^{* *}$ & $2.56^{* *}$ & -1.1 & & & $-2.94^{* *}$ & & & $9.66^{\star \star}$ \\
\hline & 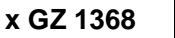 & & $686^{\star \star}$ & & & & & & & & & & & & \\
\hline Gaori & x GZ 1368 & $5.46^{\star \star}$ & $-0.59^{\star \star}$ & $6.45^{\star \star}$ & $5.98^{* *}$ & $-1.18^{*}$ & -1.45 & $1.80^{* *}$ & 0.004 & $0.007^{\star *}$ & $0.09^{\star *}$ & $30.04^{\star *}$ & $-11.13^{\star \star}$ & $-3.87^{* *}$ & $-5.06^{* \star}$ \\
\hline \multirow[t]{2}{*}{ S.E (Sij) } & $: 0.05$ & 0.76 & 0.57 & 2.44 & 1.79 & 1.1 & 1.9 & 0.5 & 0. & & & 2.37 & 3.32 & 2.36 & 1.50 \\
\hline & & & & & & 1. & & 0. & & & & C.. & 4.06 & 2.89 & 33 \\
\hline \multirow[t]{2}{*}{ S.E (Sij-Ski) } & : 0. & 1.4 & 1.1 & 4.7 & 3.4 & 2.2 & & 1.1 & & & & 4.6 & 6.4 & 4.6 & 2.92 \\
\hline & 0 & 1.80 & 1.35 & 5.80 & 4.25 & 2.73 & 4.64 & 1.35 & 0.69 & 0.004 & 0.004 & 5.63 & 7.90 & 5.63 & 3.57 \\
\hline
\end{tabular}

${ }^{\star}$ and ${ }^{* *}$ significant at 0.05 and 0.01 probability levels, respectively. 
Table (7): Estimates of heterosis as a deviation from mid and better parent of the twenty eight rice crosses for grain yield and some of its related traits under water stress conditions.

\begin{tabular}{|c|c|c|c|c|c|c|c|c|c|c|c|c|c|c|c|}
\hline \multirow{2}{*}{\multicolumn{2}{|c|}{ Genotype }} & \multicolumn{2}{|c|}{$\begin{array}{l}\text { days to } 50 \% \\
\text { heading }\end{array}$} & \multicolumn{2}{|c|}{$\begin{array}{l}\text { Plant height } \\
\text { (cm) }\end{array}$} & \multicolumn{2}{|c|}{$\begin{array}{c}\text { No. of } \\
\text { panicles/plant }\end{array}$} & \multicolumn{2}{|c|}{$\begin{array}{l}\text { Panicle length } \\
\text { (cm) }\end{array}$} & \multicolumn{2}{|c|}{$\begin{array}{c}100-\text { grain weight } \\
\text { (g) }\end{array}$} & \multicolumn{2}{|c|}{ Sterility \% } & \multicolumn{2}{|c|}{$\begin{array}{c}\text { Grain yield/plant } \\
(\mathrm{g})\end{array}$} \\
\hline & & MP & BP & MP & BP & MP & BP & MP & BP & MP & BP & MP & BP & MP & BP \\
\hline \multirow{8}{*}{\multicolumn{2}{|c|}{$\begin{array}{r}\text { Sakha 102xSakha } 104 \\
\text { x Balado } \\
\text { x Wab 450 } \\
\text { x IET 1444 } \\
\text { x Wab 878 } \\
\text { x Gaori } \\
\text { x GZ 1368 }\end{array}$}} & $-3.93^{*}$ & -0.74 & $6.87^{* *}$ & $15.25^{\star \star}$ & $23.92^{*}$ & 12.76 & 7.80 & 6.88 & -1.90 & -2.65 & 43.47 & $106.45^{\star}$ & $8.05^{\star \star}$ & $37.72^{* *}$ \\
\hline & & & & & & & 9.14 & $2.71^{\text {** }}$ & & $-4.98^{* *}$ & $-16.37^{\star *} \mid$ & $63.25^{* *}$ & & & -6.22 \\
\hline & & 17 & $7.00^{* *}$ & $13.76^{* *}$ & $29.67^{* *}$ & 22.07 & 12.57 & $-9.83^{*}$ & $-14.06^{\star \star}$ & $3.75^{\star}$ & 1.47 & $216.28^{\star \star}$ & $6.12^{* \star}$ & 4.38 & -5.45 \\
\hline & & & 0.74 & & & 3 & 9.22 & $21.23^{\star *}$ & $1.56^{* *}$ & $9.12^{\star *}$ & 1.15 & & & & 7.87 \\
\hline & & $-5.17^{* *}$ & 1.47 & $4.26^{*}$ & $24.58^{\star \star}$ & $32.24^{\star *}$ & 21.95 & $16.51^{\text {** }}$ & $5.51^{* *}$ & $-8.23^{\star *}$ & $-10.58^{\star \star} \mid$ & 2. & $3^{* *}$ & & 3.98 \\
\hline & & & 1.11 & & $15.04^{* \star}$ & -7.43 & -11.40 & $16.51^{\text {** }}$ & $15.51^{* *}$ & 0.59 & -1.92 & & & & $36.26^{* *}$ \\
\hline & & & $12.54^{*}$ & & & & -12.31 & & & & & & & & \\
\hline & & & $10.90^{*}$ & & 4.02 & & -9.07 & $11.91^{* *}$ & & $2^{* \star}$ & -1.46 & & & & $2^{* \star}$ \\
\hline \multirow{5}{*}{\multicolumn{2}{|c|}{$\begin{aligned} & \text { Sakha } 104 \text { x Balado } \\
& \times \text { Wab } 450 \\
& \text { x IET } 1444 \\
& \text { x Wab } 878 \\
& \text { x Gaori } \\
& \text { x GZ } 1368\end{aligned}$}} & & & & $15.38^{* \star}$ & & -23.0 & & & & $-3.67^{*}$ & & & & \\
\hline & & & 12.2 & 11 & & $22.58^{\star *}$ & 5.55 & 15. & 5.78 & $\left|-10.28^{\star \star}\right|$ & $-17.42^{\star \star} \mid$ & & & $22^{* *}$ & $-25.47^{\star \star}$ \\
\hline & & & $19.02^{\star \star}$ & $7.82^{\star \star}$ & $18.68^{\star \star}$ & $42.36^{\star *}$ & $20.46^{*}$ & 24. & $24.52^{\star *}$ & $-8.55^{\star \star}$ & $-10.21^{\star \star} \mid$ & 48 & $3^{\star *}$ & & $30^{* *}$ \\
\hline & & & $6.66^{\star \star}$ & -3 & $6.63^{*}$ & 16.22 & 10.23 & & 8. & & & & & & \\
\hline & & & $12.45^{\star \star}$ & & -0.73 & & -5.26 & & & & $5^{* *}$ & & & & $4^{* *}$ \\
\hline \multirow[t]{5}{*}{ Balado } & & & $10.90^{* *}$ & $*$ & $13.87^{\star \star}$ & 12.67 & -9.07 & & 9. & & $6.72^{* \star}$ & & & & $6^{* *}$ \\
\hline & & & & & & & 5.5 & & & & & & & & \\
\hline & & & 0.90 & & & $32.37^{* *}$ & 6.8 & & -1. & & $4.09^{\star *}$ & & & & $-9.57^{*}$ \\
\hline & & & & & $22^{\star \star}$ & 16.48 & 4.57 & -4.59 & -8. & ** & $-10.23^{\star \star} \mid$ & 6 & 44.8 & & 7.63 \\
\hline & & & $5.45^{\star \star}$ & & $8.18^{* *}$ & 4.9 & -7.05 & & 6. & & $-8.18^{\star \star}$ & & & & 6.12 \\
\hline \multirow[t]{4}{*}{ Wab 450} & & 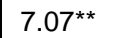 & $\mid 11.19^{\star \star}$ & $17.44^{* *}$ & $19.04^{* \star}$ & $25.92^{* *}$ & -5.55 & $14.27^{\star *}$ & $10.13^{*}$ & ** & 0.73 & -17 & $-c$ & ** & $29.07^{\star *}$ \\
\hline & & & & & & & & & & & & & & & \\
\hline & & & & * & 44 & & & 27. & 20. & -13 & 4 ** & 44 & & & 70 \\
\hline & & & $-4.90^{\star \star}$ & & & & -5.2 & & & & & & & & \\
\hline \multirow[t]{3}{*}{ |IET 1444} & & & $9.09^{* \star}$ & & & $58.00^{* *}$ & $18.50^{*}$ & $34.90^{* *}$ & 23. & & & & & & $38.92^{* *}$ \\
\hline & & & & & & $16.85^{*}$ & -3.72 & & & & $12.95^{\star *}$ & & $51^{* *}$ & & $-17.51^{\star *}$ \\
\hline & & & & & & & $14.00^{*}$ & & & & & & & & \\
\hline \multirow[t]{2}{*}{ Wab 878} & x Gaol & & $6.66^{\star \star}$ & $22.01^{\star *}$ & 49.55 & $74.24^{\star *}$ & $54.37^{\star}$ & $24.52^{\star *}$ & $24.52^{\star *}$ & $4.41^{\star \star}$ & -0.72 & 26. & $90.32^{\star *}$ & $8 \varepsilon$ & $72.56^{\star *}$ \\
\hline & & & $-2.29^{*}$ & & & & 1.73 & & 22. & -2.47 & & 239. & & & 50 \\
\hline G & & & $15.55^{\star}$ & & $30.09^{* *}$ & 6.52 & $-14.05^{\star}$ & & & & $-5.66^{* *}$ & & & & 5.20 \\
\hline \multirow{2}{*}{\multicolumn{2}{|c|}{$\begin{array}{|cc|}\text { L.S.D } & 0.05 \\
& 0.01\end{array}$}} & 1.84 & 2.13 & 3. & 4.14 & 2.27 & 2.62 & 1.6 & 1. & 0.0 & 0. & & & & 0.10 \\
\hline & & & 2.83 & 4.78 & 5.50 & 3.02 & 3.49 & 2.12 & 2.44 & 0.11 & 0.13 & & & 4.35 & 5.00 \\
\hline
\end{tabular}

${ }^{*}$ and ${ }^{* \star}$ significant at 0.05 and 0.01 probability levels, respectively. 
Table (8): Estimates of heterosis as a deviation from mid and better parent of the twenty eight rice crosses for grain yield and some of its related traits under normal conditions.

\begin{tabular}{|c|c|c|c|c|c|c|c|c|c|c|c|c|c|c|c|}
\hline \multirow{2}{*}{\multicolumn{2}{|c|}{ Geno }} & \multicolumn{2}{|c|}{$\begin{array}{l}\text { days to } 50 \% \\
\text { heading }\end{array}$} & \multicolumn{2}{|c|}{$\begin{array}{l}\text { Plant height } \\
\text { (cm) }\end{array}$} & \multicolumn{2}{|c|}{$\begin{array}{c}\text { No. of } \\
\text { panicles/plant }\end{array}$} & \multicolumn{2}{|c|}{\begin{tabular}{|c} 
Panicle length \\
$(\mathrm{cm})$
\end{tabular}} & \multicolumn{2}{|c|}{\begin{tabular}{|c|} 
100-grain weight \\
(g)
\end{tabular}} & \multicolumn{2}{|c|}{$\begin{array}{c}\text { Sterility } \\
\%\end{array}$} & \multicolumn{2}{|c|}{$\begin{array}{c}\text { Grain } \\
\text { yield/plant ( } \mathrm{q} \text { ) }\end{array}$} \\
\hline & & MP & BP & MP & BP & MP & $\mathrm{BP}$ & MP & BP & MP & BP & MP & BP & MP & BP \\
\hline \multicolumn{2}{|c|}{ Sakha 102xSakha 104} & $-5.40^{\star *}$ & -0.75 & $12.32^{\star *}$ & $14.76^{* *}$ & $60.37^{\star \star}$ & $57.38^{* *}$ & $-11.87^{\star \star}$ & $14.84^{\star \star}$ & $4.30^{\star *}$ & 1.67 & 107.27 & 122.07 & $22.31^{\star *}$ & $20.15^{\star \star}$ \\
\hline & & $-2.51^{* *}$ & 0.00 & $4.27^{\star *}$ & $6.11^{\star \star}$ & $20.69^{\star \star}$ & 9.37 & 2.29 & $-9.44^{* *}$ & $17.37^{* *}$ & $3.21^{*}$ & 50.47 & $156.49^{*}$ & $15.67^{* *}$ & 3.60 \\
\hline & & $-3.04^{* *}$ & $2.26^{*}$ & $13.16^{\star \star}$ & $16.08^{\star *}$ & 15.19 & 1.90 & $-12.92^{\star \star}$ & $-13.50 * *$ & 1.86 & -1.96 & 33.17 & & $-8.84^{\star}$ & $-10.91 *$ \\
\hline & & $-4.67^{* *}$ & 0.00 & $15.48^{\star *}$ & $19.94^{* *}$ & $39.67^{\star \star}$ & $26.58^{* *}$ & 2.06 & 1.37 & $5.20^{* *}$ & $-3.53^{\star}$ & $92.70^{\star \star}$ & $715.25^{* *}$ & $16.72^{\star \star}$ & 5.91 \\
\hline & & $-8.18^{* *}$ & $-2.63^{*}$ & -0.44 & $8.36^{\star *}$ & $22.62^{*}$ & 9.63 & $-13.14^{\star \star}$ & $\mid-15.38^{\star *}$ & -0.52 & -0.70 & 4.82 & 50 & $27.60^{* *}$ & 0.92 \\
\hline & & $7.30^{\star \star}$ & $9.41^{* *}$ & 1.8 & $6.29^{\star \star}$ & 15.32 & 8.49 & -1.47 & $-10.78^{\star \star}$ & 1.68 & $-3.88^{*}$ & $-46.64^{\star *}$ & & $36.90^{\star \star}$ & $3.20^{\star \star}$ \\
\hline & & $-7.53^{\star *}$ & $6.41^{* *}$ & $-4.94^{* *}$ & 1.92 & $29.91^{* *}$ & 4.69 & $-6.93^{* *}$ & $-9.44^{* *}$ & $13.49^{* *}$ & 1.06 & -70.83 & -56.81 & $24.34^{\star *}$ & $19.15^{\star \star}$ \\
\hline \multirow[t]{6}{*}{ Sakha 104} & $\mathbf{x}$ & -1.65 & $5.95^{\star *}$ & $4.51^{\star *}$ & $8.72^{* *}$ & 5.05 & -3.14 & -1.61 & $-10.17^{\star \star}$ & $11.77^{\star \star}$ & 0. & 245 & & $14.62^{\star \star}$ & 4.31 \\
\hline & & -1.53 & -1.03 & & $19.46^{\star *}$ & -14.90 & -25.9 & $-21.14^{\star \star}$ & $-23.30^{* *}$ & $-5.96^{* *}$ & -7.1 & $2^{* \star}$ & 348 & -4.10 & $-7.89^{*}$ \\
\hline & & $14.77^{\star \star}$ & $14.77^{* *}$ & $18.48^{\star *}$ & $25.84^{\star *}$ & $35.57^{\star \star}$ & $24.98^{* *}$ & $8.43^{* *}$ & $5.46^{*}$ & $4.49^{* *}$ & -6 . & $34.64^{*}$ & & $27.71^{\star *}$ & $17.77^{\star \star}$ \\
\hline & & & $6.86^{\star *}$ & $6.62^{\star *}$ & $18.79^{\star *}$ & $32.65^{\star \star}$ & 16.66 & $6.12^{*}$ & & & & & & $61.80^{\star \star}$ & $3.31^{\star \star}$ \\
\hline & & -1 & $5.88^{* *}$ & $3.08^{*}$ & $5.24^{\star \star}$ & $43.38^{\star \star}$ & -4.69 & -3.90 & $-10.17^{* *}$ & $-4.72^{* *}$ & -12 & $-58.92^{* *}$ & & $15.22^{\star *}$ & 5.13 \\
\hline & & & $22.68^{* *}$ & $-3.66^{* \star}$ & $5.70^{* *}$ & $20.87^{\star \star}$ & -1.16 & $7.92^{* *}$ & $7.15^{\star}$ & $4.81^{* *}$ & & 106 & & 4.25 & 1.65 \\
\hline \multirow[t]{5}{*}{ Balado } & & $-4.39^{\star \star}$ & $3.57^{\star *}$ & $13.09^{* *}$ & $13.97^{\star *}$ & 3.86 & -15.61 & $13.82^{\star \star}$ & & & & $96^{* *}$ & 72 & $-13.11^{* *}$ & $-23.74^{*}$ \\
\hline & & & 0.00 & $7.76^{* *}$ & $9.94^{\star *}$ & 9.37 & 9.37 & -4.63 & -15. & $21.18^{\star *}$ & & & & $18.25^{\star *}$ & $16.55^{\star \star}$ \\
\hline & & & 1.19 & 9.8 & $17.39^{* *}$ & $48.61^{\star \star}$ & $21.89^{* *}$ & $-9.64^{* *}$ & $-21.80^{* \star}$ & $15.67^{* *}$ & $1 . \varepsilon$ & $0^{\star *}$ & 23 & $27.10^{\star *}$ & $-7.18^{*}$ \\
\hline & & 4. & $4.76^{\star *}$ & & $9.78^{\star *}$ & $21.98^{\star \star}$ & $17.20^{*}$ & $11.07^{\star *}$ & $8.30^{*}$ & & & & & $25.11^{\star *}$ & 5.76 \\
\hline & & -11 & $4.76^{* *}$ & $5.60^{\star *}$ & $11.18^{* *}$ & 8.73 & -4.69 & $5.50^{*}$ & -4.28 & $12.12^{\star *}$ & & 205 & $5^{\star *}$ & $14.28^{\star *}$ & $6.47^{\star}$ \\
\hline \multirow[t]{4}{*}{ Wab 450} & xI & $13.84^{\star *}$ & $27.58^{* *}$ & $18.42^{* *}$ & $19.87^{* *}$ & 13.44 & -7.82 & $8.22^{* *}$ & $8.22^{* *}$ & & & & & $29.15^{\star *}$ & $14.8^{\star \star}$ \\
\hline & & -05 & 0.00 & $303^{*}$ & $9.17^{\star *}$ & 18.56 & 17.13 & $9.91^{* *}$ & 6.3 & 9.8 & & & 6 & $79.86^{* *}$ & $44.74^{\star \star}$ \\
\hline & & & $17.64^{* *}$ & 13. & $21.68^{* *}$ & $53.56^{* \star}$ & $28.84^{* *}$ & $27.81^{* *}$ & $16.44^{\star *}$ & $-10.03^{\star *}$ & & & & $63.16^{\star *}$ & $56.17^{\star \star}$ \\
\hline & & 010 & $2.04^{*}$ & $717^{\star *}$ & $11.92^{\star *}$ & $75.99^{\star \star}$ & $29.40^{* *}$ & 209 & & a? & & $6^{\star \star}$ & & $36.88^{\star *}$ & $8.32^{* \star}$ \\
\hline \multirow[t]{3}{*}{ IET 1444} & $\mathrm{xWa}$ & $25.51^{\text {** }}$ & $26.80^{* *}$ & $17.26^{\star *}$ & $22.69^{\star *}$ & $39.06^{* \star}$ & 14.06 & $20.52^{* *}$ & $16.65^{\star \star}$ & $30.38^{* *}$ & *** & $97.89^{* *}$ & $42^{* *}$ & $62.82^{* *}$ & $20.00^{\star \star}$ \\
\hline & & & $170 *$ & & $25.87^{\star *}$ & & $34.36^{* *}$ & $6.74^{\star}$ & & & & & & 1.29 & $-13.33^{*}$ \\
\hline & & -0.9 & $8.24^{* *}$ & $6.51^{* *}$ & $9.85^{\star *}$ & $39.58^{\star \star}$ & $22.34^{\star *}$ & -2.09 & -4.11 & $13.34^{* *}$ & & $-78.22^{\star *}$ & 8 & $7.43^{\star}$ & 1.46 \\
\hline \multirow[t]{2}{*}{ Wab 878} & & -1.0 & $7.05^{\star \star}$ & $16.25^{\star *}$ & $32.51^{* *}$ & $82.05^{\star \star}$ & $54.27^{* *}$ & 0.00 & $-11.53^{* \star}$ & $13.05^{* *}$ & & & & $83.76^{\star *}$ & $53.12^{\star \star}$ \\
\hline & & -8.41 & -1.01 & & $10.39^{\star *}$ & $50.79^{\star \star}$ & 11.75 & 1. & & $22.77^{* *}$ & & 424 & & $20.65^{\star *}$ & $-7.5^{*}$ \\
\hline Gaori & x GZ 1368 & -1.00 & $16.47^{* *}$ & $9.35^{\star *}$ & $22.73^{* *}$ & $23.60^{\star \star}$ & 4.69 & 4.59 & -2.87 & $11.20^{* *}$ & $4.36^{*}$ & $-53.68^{\star \star}$ & 40 & 2.77 & $-7.5^{*}$ \\
\hline \multirow{2}{*}{\multicolumn{2}{|c|}{ L.S.D 0.05}} & 1.60 & 1.82 & 2.8 & 3.26 & 2.96 & 3.42 & 1. & 1. & 0. & & & & 2.60 & 3.00 \\
\hline & & 2.12 & 2.44 & 3.75 & 4.33 & 3.93 & 4.54 & 1.51 & 1.72 & 0.11 & 0.13 & 5.13 & 5.93 & 3.45 & 3.99 \\
\hline
\end{tabular}

${ }^{*}$ and ${ }^{* *}$ significant at 0.05 and 0.01 probability levels, respectively. 
Table (9): Estimates of phenotypic correlation coefficients among all possible pairs of grain yield and its related traits under water stress and normal conditions.

\begin{tabular}{|c|c|c|c|c|c|c|c|c|c|c|c|c|}
\hline \multirow[b]{2}{*}{ Character } & \multicolumn{2}{|c|}{1} & \multicolumn{2}{|c|}{2} & \multicolumn{2}{|c|}{3} & \multicolumn{2}{|c|}{4} & \multicolumn{2}{|c|}{5} & \multicolumn{2}{|c|}{6} \\
\hline & D & $\mathbf{N}$ & D & $\mathbf{N}$ & D & $\mathbf{N}$ & D & $\mathbf{N}$ & $\mathbf{D}$ & $\mathbf{N}$ & D & $\mathbf{N}$ \\
\hline 1- Days to $50 \%$ heading & - & - & & & & & & & & & & \\
\hline 2- Plant height (cm) & 0.180 & 0.220 & - & - & & & & & & & & \\
\hline 3- No. of panicles /plant & 0.159 & 0.191 & 0.201 & 0.243 & - & - & & & & & & \\
\hline 4- Panicle length (cm) & $0.424^{\star \star}$ & $0.495^{\star \star}$ & $0.574^{\star \star}$ & $0.547^{\star \star}$ & $-0.407^{\star \star}$ & $-0.445^{\star \star}$ & - & - & & & & \\
\hline 5- 100-grain weight (g) & $0.406^{\star \star}$ & $0.429^{* \star}$ & 0.206 & 0.127 & $-0.295^{\star}$ & $-0.290^{*}$ & $-0.312^{*}$ & $-0.331^{*}$ & - & - & & \\
\hline 6- Sterility \% & $-0.368^{*}$ & $-0.298^{*}$ & 0.238 & 0.262 & $0.345^{\star}$ & $0.302^{*}$ & $0.385^{\star}$ & $0.365^{*}$ & 0.227 & 0.190 & - & - \\
\hline 7- Grain yield (g) & 0.123 & 0.147 & 0.208 & 0.219 & $0.563^{* *}$ & $0.490^{* *}$ & $0.330^{*}$ & $0.383^{*}$ & $0.659^{\star *}$ & $0.598^{\star \star}$ & $-0.375^{\prime}$ & $-0.337^{\star}$ \\
\hline
\end{tabular}

${ }^{*}$ and ${ }^{* *}$ significant at 0.05 and 0.01 probability levels, respectively. 